\title{
Article \\ An Alternative Tool for Intra-Row Weed Control in a High-Density Olive Orchard
}

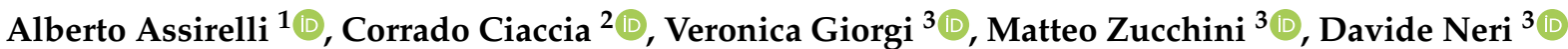 \\ and Enrico Maria Lodolini ${ }^{4, *}$ (D)
}

1 Council for Agricultural Research and Economics, Research Centre for Engineering and Agro-Food Processing, 00015 Monterotondo, Italy; alberto.assirelli@crea.gov.it

2 Council for Agricultural Research and Economics, Research Centre for Agriculture and Environment, 00184 Rome, Italy; corrado.ciaccia@crea.gov.it

3 Department of Agricultural, Food and Environmental Sciences, Marche Polytechnic University, 60131 Ancona, Italy; v.giorgi@staff.univpm.it (V.G.); m.zucchini@pm.univpm.it (M.Z.); d.neri@staff.univpm.it (D.N.)

4 Council for Agricultural Research and Economics, Research Centre for Olive, Fruit and Citrus Crops, 00134 Rome, Italy

* Correspondence: enricomaria.lodolini@crea.gov.it

Citation: Assirelli, A.; Ciaccia, C. Giorgi, V.; Zucchini, M.; Neri, D.; Lodolini, E.M. An Alternative Tool for Intra-Row Weed Control in a High-Density Olive Orchard.

Agronomy 2022, 12, 605. https:// doi.org/10.3390/agronomy12030605

Academic Editors: Sudheesh Manalil and Anestis Karkanis

Received: 7 February 2022

Accepted: 25 February 2022

Published: 28 February 2022

Publisher's Note: MDPI stays neutral with regard to jurisdictional claims in published maps and institutional affiliations.

Copyright: (C) 2022 by the authors. Licensee MDPI, Basel, Switzerland. This article is an open access article distributed under the terms and conditions of the Creative Commons Attribution (CC BY) license (https:// creativecommons.org/licenses/by/ $4.0 /$ )

\begin{abstract}
In high-density olive orchards, weed control along the row is pivotal to avoid the competition between the young trees and the weeds to promote a strong vegetative growth of the olives during the first years after planting. Two different mechanical weeders were compared in a highdensity olive orchard (1250 trees $\mathrm{ha}^{-1}$ ) planted in 2019. An intra-row hoeing machine (Control) and an alternative system with a high-pressure water blast (Grass Killer) were compared. The treatments were carried out in summer and autumn. The effects of the two control systems were assessed through the weed soil coverage and indirectly through the growth of olive trees. The effect on weeds in summer was marked without showing significant differences between the applied treatments, even if the Grass Killer did not eradicate totally the weeds. In autumn, the hoeing machine showed a higher weeding capacity, even though the presence of weeds along the row treated with the high-pressure water weeder can contribute to reduce the soil moisture in wintertime. No differences were seen for the young olive tree growth. Results showed a good weeding capacity of the alternative machine, and its use can be managed in combination with other mechanical systems.
\end{abstract}

Keywords: green cover management; plant growth; competition; water weed-killing machine; Olea europaea

\section{Introduction}

The renovation of the olive orchards with new intensive planting systems that allow earlier and more abundant yield, and complete mechanization of harvest, is nowadays a reality [1]. Olive growing is expanding in new areas of the world using high-density planting orchards (or as it is known, super-high-density, SHD), generally using few cultivars that recorded overall adaptability to diverse climatic conditions, early bearing, low-vigour and high-yield efficiency characteristics [2-5]. Strong vegetative growth of the plantlets is required during 2-3 years after planting to form the hedgerow and allow an early onset of fruit production. A previous study under the same pedoclimatic conditions has highlighted different canopy behaviours linked to the different cultivars [6]. Weed control along the row is pivotal to reduce the competition for water and nutrients during this early critical period of the tree growth [7]. This competition during the early stages after plantation can be very strong, thus reducing the growth of the young olive trees and delaying the onset of fruit production [8] as reported by different authors [9,10]. In addition, in intensive cropping systems, water provided by drip irrigation contributes to the accelerate vegetative 
growth and the onset of fruit production after planting [11] and regulates the vegetativereproductive balance during the adult phase. At the same time irrigation stimulates the emergence and development of weeds along the row, requiring more care to control them [7].

This control can be carried out by two main strategies: (i) directly eliminating the weeds (direct control); (ii) limiting their development by spreading partially fermented or unfermented organic material on the surface, thus increasing the organic content at the same time [6]. Direct control (physical or chemical) depends by the operator's choice of intervention and by the specific functional tool used [12].

Since the trees are planted in rows, weed requires a different management in the intra-row and inter-row soil surface, depending on the shading level of the trees [13] and the planting density [14]. The inter-row can be managed by natural ground cover (green cover) to reduce the run-off and soil erosion, and increase the organic matter content [8], the rainfall infiltration and water retention, the overall biodiversity and biocenosis of the soil and the machine transit ability [15-18]. This management allows the use of automatic or semi-automatic guidance systems to improve the precision of work [19]. Sown cover crops with single species or a polyculture (legume and grass species) can be also used [20]. Other solutions that do not affect the soil profile may involve direct mowing with displacement or removal of biomass for other uses such as, for example, the use designed for riverbed maintenance [21]. On the other hand, the intra-row represents the strip where weed control is more difficult, but pivotal because of the higher direct competition with the root system of the trees. For this reason, intra-row weed management in high-density olive orchard represents a challenge [22].

Periodical tillage to remove weeds has been proven to dramatically reduce weed communities in olive orchards and the related ecosystem services they can provide [20]. Moreover, with the intensification of the cultural practices for this species, alternative solutions have been recently suggested for inter- and intra-row weed control, and the maintenance of no-tilled inter-row is promoted $[23,24]$. The machines traditionally used for inter-row tillage can also be customised for different types of applications, in particular, to reduce the fine soil fraction responsible for the mineralisation of the organic matter along the lines, as for what is done when harvesting surface rhizomes with a precise calculation of the tillage area and accurate sizing of the potting soil [25]. For the use of chemical herbicides, the results were effective, easy to apply and cheap, but with a potential negative impact on the environment, even when applied only in the intra-row-strip $[26,27]$. In the last decade, an increasing awareness about soil and water pollution and biodiversity reduction promoted the adoption of alternative, sustainable and eco-friendly solutions [28,29].

Weed control is mentioned as the most pressing factor for organic farms and a crucial point in the conversion from conventional to organic orchard management [30]. In this context, intra-row management with physical methods is desirable for environmental sustainability and soil biodiversity richness [28,29], but also to less depress the initial development of the young tree [31,32].

Among the proposed solutions, physical weed control seems to be the most sustainable system, even allowed in organic farming. Currently, the use of small tow-behind operating machines is preferred: a slight effect on the soil profile by breaking the very early centimetres of the surface is obtained, and the use of telescopic extensions, hydraulic feelers or optical sensors allows the weed control very close to the single tree of the crop [13,29]. Additional systems for physical weed control are reported by Mia and co-authors, [29] and are based on the use of fire or high-pressure water.

The high-pressure water approach is a technical innovation for weeding, and accurate studies of the pressures required for each specific type of weed and its vegetative stage should, therefore, be carried out following the example of what has been done for the release force of thinned fruit [33]. High-pressure water weeding applications have been studied for over 15 years [34] and appear to be a feasible method of physical weeding in organic farming [32]. Only since the beginning of the twenty-first century, the technique of 
high-pressure water has been proposed as a method of physical weeding [35,36], studying the setting up according to the crop where it was applied [34,37].

The objective of our study was to assess the effect of an alternative high-pressure water blast system in comparison with a hoeing machine for the intra-row weed control during the very early stage after planting in a high-density olive orchard. We specifically hypothesized that the high-pressure blast system: (i) has a comparable effect to the classic hoeing weed control, (ii) has a lesser effect in reducing the weed biodiversity and (iii) does not induce damage on the young olive trees.

\section{Materials and Methods}

\subsection{Site and Experimental Setup}

The trial was carried out in the high-density olive orchard of the "Olive Orchard Innovation Long-term experiment" (OOIL) located at the experimental farm of the CREA-OFA in Rome, central Italy (Lat. $41^{\circ} 47^{\prime} 20.4^{\prime \prime} \mathrm{N}$, Long. $12^{\circ} 33^{\prime} 42.2^{\prime \prime}$ E, Alt. $100 \mathrm{~m}$ a.s.1.). The experimental field has a surface of more than 1 hectare and is arranged according to a randomized block design including five olive cultivars with different soil floor managements. The trees were planted in October 2019 at $4 \mathrm{~m} \times 2 \mathrm{~m}$ (1250 trees per hectare). The soil had a sandy-loam texture and a neutral $\mathrm{pH}$ and the olive plants were drip irrigated with a single line per tree row and $1.6 \mathrm{Lh}^{-1}$ emitters placed at $0.5 \mathrm{~m}$ interval along the line. A $12 \mathrm{~h}$ drip irrigation was weekly applied from June to August and trees received a total of $1.05 \mathrm{~m}^{3}$ (total $1.363 \mathrm{~m}^{3} \mathrm{ha}^{-1}$ ) along the whole season. Each tree was fertilized with $65 \mathrm{~g}$ of urea (46-0-0 NPK) in May and $100 \mathrm{~g}$ of Nitrophoska Gold (15-9-15 NPK) in June and July for a total of $60 \mathrm{~g}$ of $\mathrm{N}$ per tree in 2020. The experiment was carried out on "Maurino" olive cultivar during the growing season 2020.

Meteorological data were obtained from an agrometeorological station of the Integrated Agro-meteorological Service of Lazio regional agency for agricultural development and innovation (Agenzia Regionale per lo Sviluppo e 1'Innovazione dell'Agricoltura del Lazio; ARSIAL), located at about $6.5 \mathrm{~km}$ from the experimental field. The meteorological conditions during the year of the trial in the experimental field are given in Figure 1.

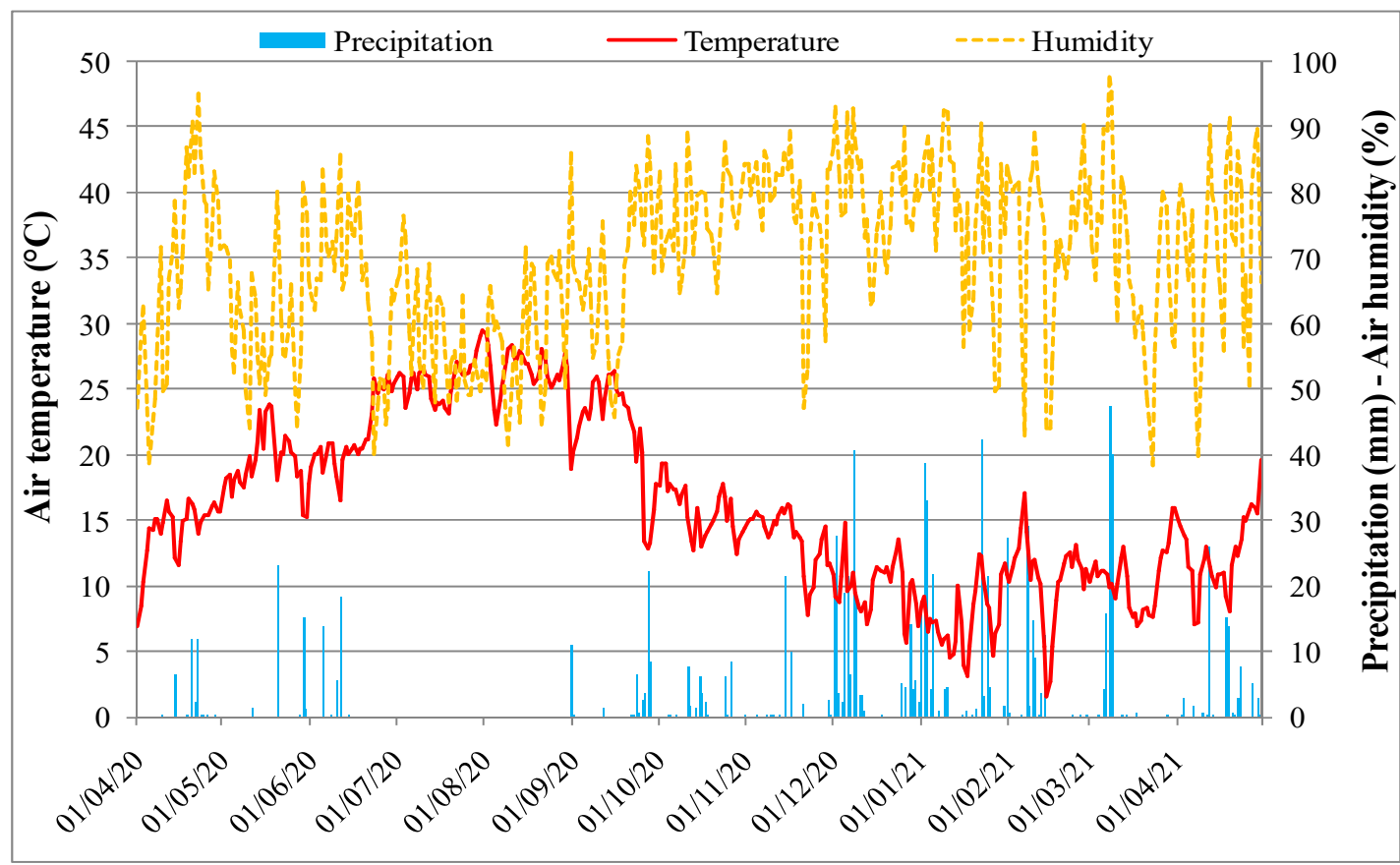

Figure 1. Trends of mean daily air temperature, mean daily air humidity and daily amount of precipitation. 
Starting from 13 June until 22 September 2020, the daily mean air temperature remained above $20^{\circ} \mathrm{C}$, except for 31 August when a short atmospheric perturbation with rain showers occurred. The highest mean air temperature $\left(29^{\circ} \mathrm{C}\right)$ was registered on $31 \mathrm{July}$. In the same period, the air humidity recorded the lowest values (around 60\%), whereas from October 2020 to April 2021, it remained around 70\%. A total absence of rainfall occurred from mid-June to 31 August 2020, whereas September, October and November 2020 registered a total rainfall of around 45, 39 and $37 \mathrm{~mm}$, respectively. December 2020 and January 2021 resulted in the rainiest months of the period (205 and $228 \mathrm{~mm}$, respectively) and total rainfall for the February-April 2021 period was $260 \mathrm{~mm}$.

A weeding machine with a high-pressure water system (Grass Killer, GK) was compared to a hoeing machine (traditional mechanical method used for weeding management: Control) along the intra-row. The specifications of the Grass Killer machine and the hoeing machine are reported in Table 1. The Grass Killer machine works by applying high-pressure water blasting to treat the under row, using water at room temperature without heating. The Grass Killer machine features a piston pump fed from a trailed water tank (Figure 2). The working tool shoved a circular head with four nozzles of $0.16 \mathrm{~mm}$ diameter. The header rotation speed was set at $600 \mathrm{rpm}$ by a hydraulic motor, and three different working speeds were tested: 1.2, 1.7 and $2.6 \mathrm{~km}$ per hour (GK-1.2, GK-1.7 and GK-2.6, respectively).

Table 1. Specifications of the machines adopted used in the field tests.

\begin{tabular}{|c|c|c|}
\hline & Parameter & Value \\
\hline \multirow{8}{*}{ Grass Killer } & Water pressure (bar) & 1000 \\
\hline & Cylinder head diameter $(\mathrm{cm})$ & 38 \\
\hline & Number of nozzles & 4 \\
\hline & Diameter of nozzles (mm) & 0.16 \\
\hline & Rotation speed of the nozzles (rpm) & 600 \\
\hline & Work width $(\mathrm{cm})$ & 38 \\
\hline & Water flow $\left(1 \min ^{-1}\right)$ & 0.5 \\
\hline & Working speed $\left(\mathrm{km} \mathrm{h}^{-1}\right)$ & $1.2-1.7-2.6$ \\
\hline \multirow{5}{*}{ Hoeing machine } & Engine power $(\mathrm{kW})$ & 35 \\
\hline & Working width (cm) & 80 \\
\hline & Rotation speed (rpm) & 180 \\
\hline & Tillage depth $(\mathrm{cm})$ & 10 \\
\hline & Working speed $\left(\mathrm{km} \mathrm{h}^{-1}\right)$ & 3 \\
\hline
\end{tabular}
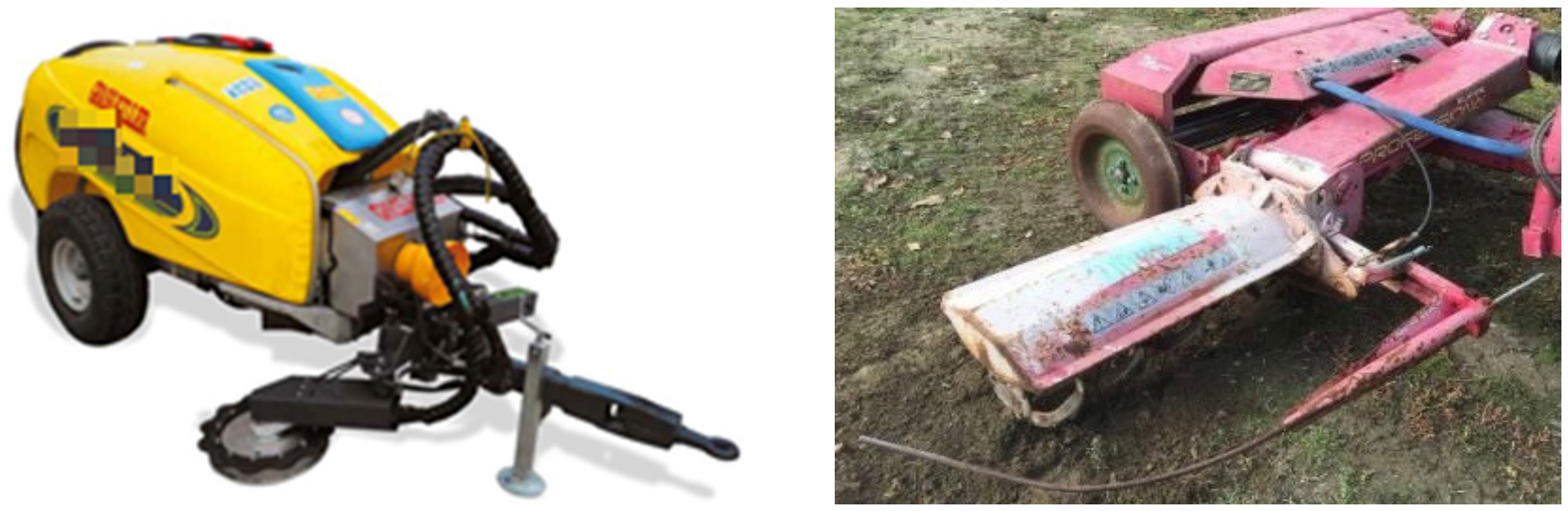

Figure 2. Grass Killer machine (left) and hoeing machine (right).

In addition to the working speeds identified, the water weed control also allows the speed of the nozzle plate to be varied, directly influencing the distance of the consecutive passes of the vertical cuts, the main agents of weed control. Some tests were carried out at different speeds, noting that the manufacturer also provides specific software for this 
purpose, allowing the speed and number of nozzles to be entered based on the speed of rotation of the plate. For the tests carried out, given the low working speeds adopted, less than $3 \mathrm{~km} \mathrm{~h}^{-1}$, a fixed rotation speed of $600 \mathrm{rpm}$ was maintained. This choice meant that between the minimum speed of 1.2 and the maximum of $2.6 \mathrm{~km} \mathrm{~h}^{-1}$, with the same number of nozzles, the distance between the individual consecutive passes was more than doubled, providing useful information on the efficiency of treatment with distances between 1 and $3 \mathrm{~cm}$ of consecutive vertical cutting passes. Further investigations are underway to also define how these settings may influence not only the herbicidal effect but also water evaporation and oxidation of organic matter.

As far as the quality of work is concerned, it is necessary to consider how the two machines are structurally and functionally very different: while the inter-row hoe acts by cyclically picking up and consecutively detaching portions of soil with the crushing of both the soil and the biomass component, the hydraulic weeder acts by a consequential and vertical rotary cut impressed by the rotation speed of the horizontal plate. As a result, the weeding effect is diverse, and the working widths treated are also uneven. In order to assess the quality of the work, the areas outside and inside the squares were specifically analysed in terms of destruction of the plant biomass developed and interaction with the soil profile. The experiment was carried out on two 130-m-long rows (about 65 trees per each row) alternating three forward speeds of the Grass Killer machine with the hoeing machine (Control). Each treatment was tested on at least 20 consecutive trees in each row.

Measurements were performed in ten trees in the central portion of the 20 subjected to the different GK and hoeing machine treatments.

Tests were executed in two different periods of the season: mid-June (the 16th) and mid-November (the 11th), corresponding to the stages with the maximum development of the natural cover (i.e., spring and autumn). The first test, originally scheduled for the second half of May, was postponed due to the restrictions following the SARS-CoV pandemic.

\subsection{Measurements}

The working quality of the three studied forwarding speeds of the Grass Killer machine was evaluated on the terminated weeds and the soil surface immediately after the waterpressure blast application in November 2020 and using frames of $0.2 \times 0.2 \mathrm{~m}$, which identified specific working areas. This system made it possible to obtain a double evaluation of the row and of the specific weeds present in the area delimited by the reference frames.

At the beginning and at the end of the growing season, plant growth was measured, recording the trunk diameter at $20 \mathrm{~cm}$ above the ground to calculate the trunk cross sectional area (TCSA) and the total height of the tree. At the end of the growing season, the amount of pruning material removed along the trunk from ground up to $60 \mathrm{~cm}$ was weighed for each young tree.

Leaf water status was assessed on 4 August 2020 by measuring the relative water content (RWC). For each treatment, RWC was determined from 2 leaves selected from the central portion of 1-year-old shoots of 12 trees per treatment. Leaves were detached, sealed in a plastic bag and taken immediately to the laboratory to determine the leaf water status.

The physiological status of the trees subjected to the different treatments was checked on 3 August 2020. Six plants for each treatment were chosen to measure gas exchange. Two young leaves per tree were sampled, along the median segment of shoots. The measurements of gas exchange were carried out on clear days at 11:00-13:00 using a programmable, open-flow gas exchange portable system (LI-6400, Li-COR Inc., Lincoln, NE, USA).

The soil temperature and relative humidity at $10 \mathrm{~cm}$ depth were recorded on 20 July 2020 and on 19 January 2021, for the June and November test, respectively, and for both weed managements. Six to nine sampling points for each treatment were used to measure the soil temperature and moisture using a digital portable thermo and moisture meter (Turoni, Forlì, Italy). 
Photographs of the intra-row soil surface between two consecutive trees were taken per each forward speed of the Grass Killer machine and for the Control to estimate visually the percentage of weed cover and the periodical evolution of the spontaneous species of the grass cover within a frame of $1.0 \times 1.0 \mathrm{~m}$ of soil surface. Three surveys of the grass cover evolution were carried out for the June test: on 16 June 2020 (before the weed treatments) and then repeated on 18 June 2020 and on 3 July 2020, 2 and 17 days after the treatment, respectively. Weed community evolution was monitored at the species level for the November test on four different moments by positioning 3 square frames $\left(1.0 \times 1.0 \mathrm{~m}^{-1}\right)$ per treatment: on 11 November 2020 (before and immediately after the weed control), 16 December 2020, 19 January 2021 and 7 April 2021, 35, 69 and 147 days after the treatment, respectively. The cover assessment allowed to provide total weed cover, TWC (\% covered by the whole community on 1 square meter), single species covers ( $\%$ covered by the species on 1 square meter), perennials incidence (\% of not annual species, giving information about the ability of the plants to grow during two or more seasons and the difficulties associated in weed removal), species richness, $\mathrm{R}\left(\mathrm{n}^{\circ}\right.$ species per square meter per treatment), and evenness, E. Evenness (Maguraano, 2013) was based on the Pielou index as: H/Hmax, where H is Shannon-Weaver index (1) and Hmax is the base-e logarithm of R.

$$
\underset{\mathrm{i}=1}{\mathrm{R}}=-\sum(\mathrm{Pi} * \ln \mathrm{Pi}) ; \times
$$

where

" $\mathrm{Pi} "=$ proportion of a given species relative to the total number of species found in the ith sample

"ln $\mathrm{Pi}^{\prime \prime}=$ natural logarithm of Pi

" $\mathrm{R}$ " = number of species found in the ith sample

Root development within the different intra-row soil management was evaluated on three dates during the experimental period: 3 July (17 days after first treatment execution), 4 November (141 days after first treatment execution) and 8 April (155 days after second treatment execution). Soil samples were collected with a manual auger (diameter $7.0 \mathrm{~cm}$, length $15.0 \mathrm{~cm}$ ) removing superficial soil $(2.0-3.0 \mathrm{~cm})$. Samples were collected for each treatment and control, $30 \mathrm{~cm}$ distance from the olive plant along the row. Samples were dried in a stove at $60^{\circ} \mathrm{C}$ until constant weight and then weighed. They were then soaked, and soil separated from roots with the help of sieves and tweezers. Washed roots and root fragments of olive trees were positioned in transparent paper and scanned (HP Scanjet G4050). Roots were dried and weighed, while images were processed through WinRHIZO (Regent Instrument Inc., Quebec, QC, Canada) to obtain root length and average diameter.

\subsection{Data Analysis}

The time $\left(\mathrm{h} \mathrm{ha}^{-1}\right)$ and the cost (Euros ha ${ }^{-1}$ ) of the high-pressure weeding system versus the mechanical control were calculated in each test. The cost-benefit analysis was calculated based on a local association of agricultural machines subcontracting [38], crossing data on reduction of herbicide use and water saving. This tariff included the costs of the fuel and the oil used for both the high-pressure system and the hoeing machine; the cost of the intervention was calculated considering the working capacity ( $\mathrm{h} \mathrm{ha} \mathrm{h}^{-1}$ ) of the weeding devices and the average cost of subcontracting in Central Italy (both the operator and the tractor 167.00 Euros ha ${ }^{-1}$ ) [38]. The official rental price list does not still include data for the tested alternative system, but price, duration and annual use are estimated by using available data for a spraying machine with the adoption of more recent security devices (e.g., the health and the environment protection), in compliance with the regulations introduced by the National Action Plan for the sustainable use of plant protection products [39]. Moreover, the machine has lower wear levels than an inter-row milling machine but higher commercial value, tractor with power greater than $42 \mathrm{~kW}$ 
hourly consumption of $9 \mathrm{Lh}^{-1}$ to which it is possible to apply a cost of $55.00 \mathrm{Euros} \mathrm{h}^{-1}$ equal to 216 Euros ha $^{-1}$ [40].

One-way ANOVA was performed and in presence of significant differences, the TukeyKramer (HSD) test at $p<0.05$ was used for mean separation. All statistical analysis was performed using the JMP 13.0 software (SAS Institute, Cary, NC, USA).

\section{Results}

\subsection{Weed Control}

The effects of the Grass Killer and the hoeing machine (Control) on weed termination were similar, and very low emergence of new weeds was recorded in summer 2020. In particular, the original weed community, characterized by a mean cover of $70 \%$ and the dominant presence of Anacyclus radiatus (Lois.) and less frequent species (Trifolium arvense L., Matricaria chamomilla L., Raphanus raphanistrum L.) showed an almost total removal on the row, with the exception of the individuals most intimately in contact with the olive trees at the time of treatment, regardless of the speed at which mechanical weeding was carried out. Two weeks after treatment, the community evolved with the sporadic emergence of species typical of the period (Amaranthus retroflexus L., Portulaca oleracea L.), residuals of spring community (Fumaria officinalis L., Lolium multiflorum Lamark) and a dominance of $R$. raphanistrum, $A$. radiatus, T. arvense. Due to the absence of rainfall in the second half of June (Figure 1) and the localized irrigation, the weed community showed a very low coverage index without significant differences among the three tested speeds, ranging between 5 an 12\%. Starting from September 2020, new weeds were found but soil coverage percentage was limited to the wet area below the irrigation drippers (Figure 3). No significant differences were seen between the tested GK treatments and the Control (data not shown).

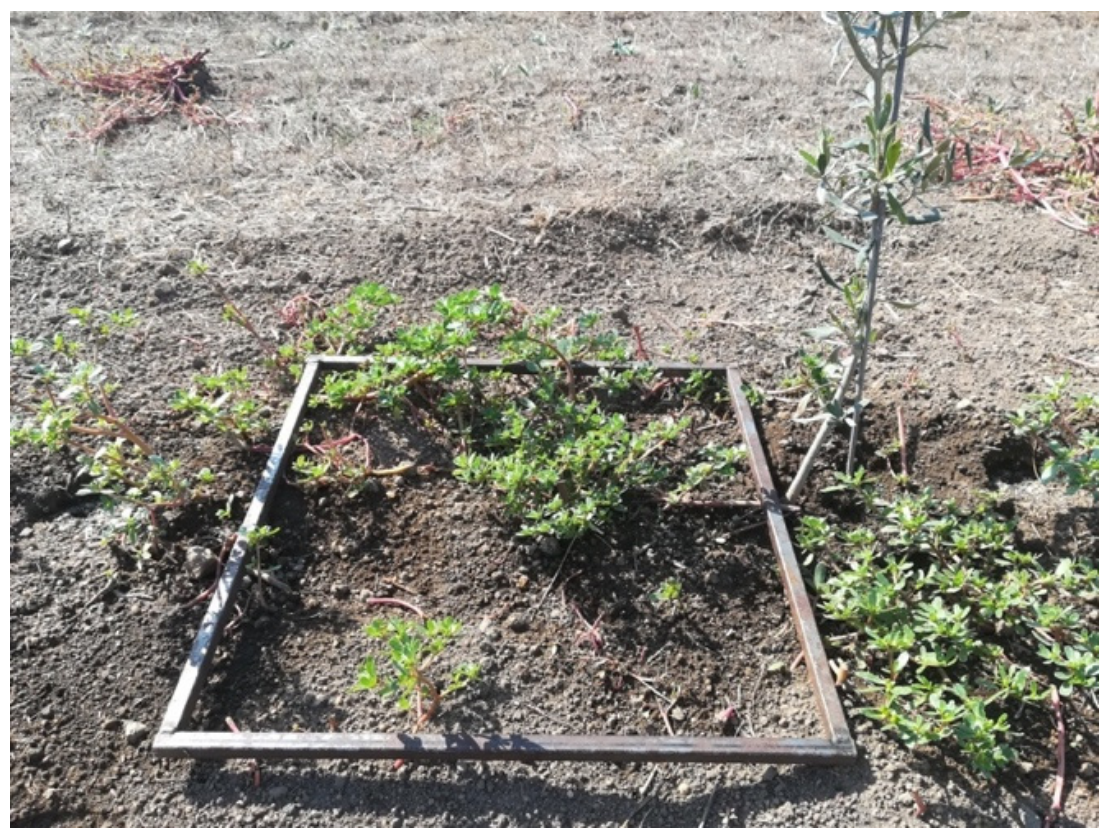

Figure 3. Weed emergence and soil coverage in GK 1.2 forward speed treatment in September 2020. New weeds are limited to the wet area below the drip irrigation.

Weed soil coverage was 100\% along the rows of the young high-density olive orchard immediately before the mid-November test. After the execution of the weed termination (November the 11th 2020) with the Grass Killer machine and the hoeing machine, a stronger weeding effect was recorded on the lower forward speed of the GK $\left(1.2 \mathrm{~km} \mathrm{~h}^{-1}\right)$ compared to the higher one $\left(2.6 \mathrm{~km} \mathrm{~h}^{-1}\right)$, which showed a reduced weeding capacity in the central portion of the treated stream and a greater weed coverage (Figure 4). 

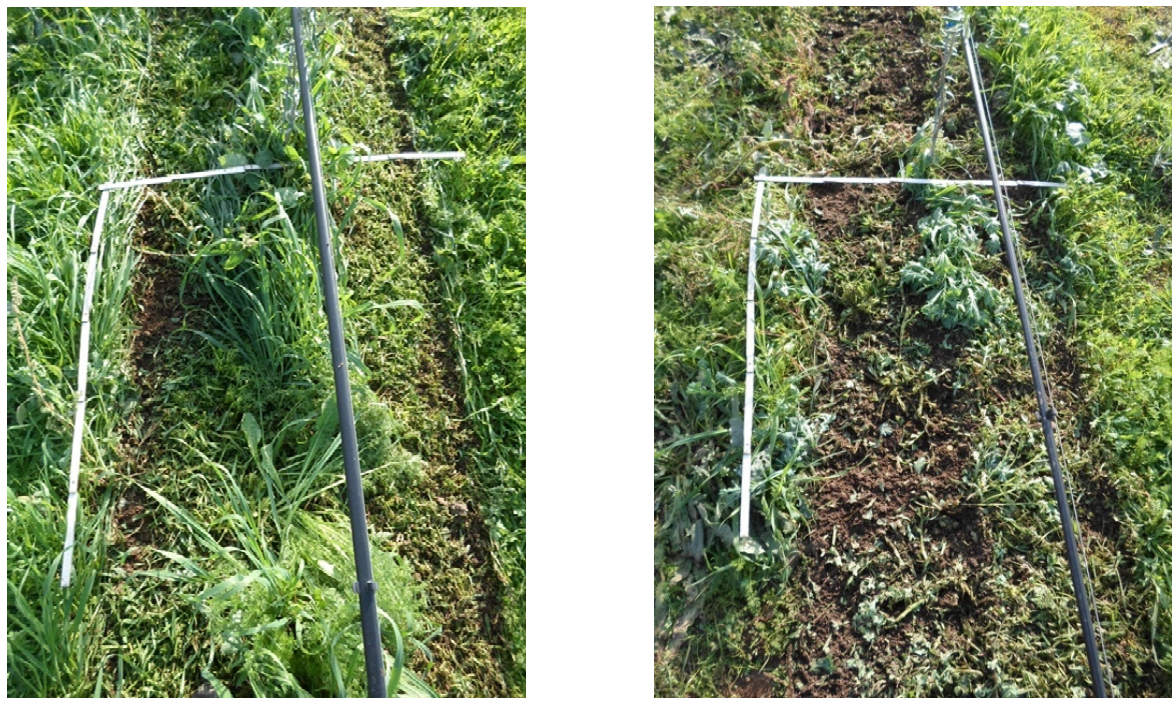

Figure 4. Weed soil coverage (\%) immediately after the Grass Killer test on 11 November 2020. Left and right picture represent GK 2.7 and GK 1.2 forward speeds, respectively.

On the other hand, the hoeing machine (Control) showed a very high weeding capacity with $0 \%$ weed soil coverage along the row. The manufacturer is implementing a larger diameter head $(>40 \mathrm{~cm})$ to make the two technologies comparable. The working speed is directly affected by the rotation speed of the operating head and the number of nozzles in the operating head and, therefore, the efficiency in terms of weed destruction and working depth are directly correlated to these parameters.

Results of the second test (November 2020) on the weed community structure and evolution are reported in Tables 2 and 3 . The weed community was similar in the three treatments before the Control (Table 2). The hoeing strategies confirmed the higher weed control accuracy, reducing the total cover (\%) to $0 \%$, whereas the GK 2.6 showed a lower effectiveness of the other Grass Killer advancing speeds with a $60 \%$ of total cover vs. 31 and $27 \%$ of GK 1.2 and GK 1.7, respectively (Table 2). The three Grass Killer treatments also showed significant differences for the other community parameters, with the lowest species richness, evenness and perennials incidence (Malva sylvestris L., Hypochaeris radicata L., Rumex crispus L., Daucus carota L., Cichorium intybus L.) in the GK 1.2 and the highest in GK 2.6. In particular, GK 1.7 showed a 0\% value of perennials followed by GK 1.2 (4\%) and then GK 2.6 $(16 \%)$, the latter not modifying the incidence of this group on the weed whole community.

Table 2. Weed community structure before and immediately after the tested weed control practices (11 November 2020).

\begin{tabular}{|c|c|c|c|c|c|}
\hline & & Total Cover (\%) & $\mathbf{R}$ & E & Perennials (\%) \\
\hline \multirow{6}{*}{$\begin{array}{l}\text { Before weed } \\
\text { control }\end{array}$} & Control & 100 & 6.4 & 0.73 & 19.4 \\
\hline & GK 1.2 & 90.0 & 6.0 & 0.82 & 13.3 \\
\hline & GK 1.7 & 100 & 9.0 & 0.70 & 13.2 \\
\hline & GK 2.6 & 100 & 7.3 & 0.68 & 13.5 \\
\hline & Mean & 98.3 & 6.9 & 0.73 & 16.4 \\
\hline & Significance & n.s. & n.s. & n.s. & n.s. \\
\hline \multirow{6}{*}{$\begin{array}{l}\text { After weed } \\
\text { control }\end{array}$} & Control & 0.0 & - & - & - \\
\hline & GK 1.2 & $30.7 \mathrm{~b}$ & $3.67 \mathrm{~b}$ & $0.56 \mathrm{~b}$ & $4.17 \mathrm{~b}$ \\
\hline & GK 1.7 & $26.0 \mathrm{~b}$ & $5.00 \mathrm{ab}$ & $0.85 \mathrm{a}$ & $0.00 \mathrm{c}$ \\
\hline & GK 2.6 & $60.0 \mathrm{a}$ & $8.33 \mathrm{a}$ & $0.88 \mathrm{a}$ & $15.7 \mathrm{a}$ \\
\hline & Mean & 38.9 & 5.67 & 0.76 & 6.61 \\
\hline & Significance & $*$ & * & * & $* * *$ \\
\hline
\end{tabular}

GK-1.2, GK-1.7 and GK-2.6 indicate the Grass Killer treatments at 1.2, 1.7 and $2.6 \mathrm{~km}$ per hour working speeds, respectively. Control $=$ hoeing machine. The mean values in each column followed by different Roman letters are significantly different according to ${ }^{*} p \leq 0.05 ;{ }^{* * *} p \leq 0.001$. $\mathrm{R}=$ richness and $\mathrm{E}=$ evenness. 
Table 3. Weed community structure at 35, 69 and 147 days after the tested weed control practices (second test, November 2020).

\begin{tabular}{|c|c|c|c|c|c|}
\hline & & Total Cover (\%) & $\mathbf{R}$ & $\mathbf{E}$ & Perennials (\%) \\
\hline \multirow{6}{*}{$35 \mathrm{DAT}$} & Control & $9.67 \mathrm{~d}$ & 4.7 & $0.80 \mathrm{a}$ & $19.2 \mathrm{a}$ \\
\hline & GK 1.2 & $41.0 \mathrm{c}$ & 3.7 & $0.85 \mathrm{a}$ & $8.33 \mathrm{a}$ \\
\hline & GK 1.7 & $61.7 \mathrm{~b}$ & 5.3 & $0.56 \mathrm{~b}$ & $0.13 b$ \\
\hline & GK 2.6 & $80.0 \mathrm{a}$ & 5.3 & $0.85 \mathrm{a}$ & $9.52 \mathrm{a}$ \\
\hline & Mean & 35.3 & 4.7 & 0.78 & 12.6 \\
\hline & Significance & $*$ & n.s. & $* *$ & $*$ \\
\hline \multirow{6}{*}{$69 \mathrm{DAT}$} & Control & $14.0 \mathrm{~d}$ & 4.6 & $0.85 \mathrm{a}$ & 15.0 \\
\hline & GK 1.2 & $35.7 \mathrm{c}$ & 6.7 & $0.91 \mathrm{a}$ & 14.8 \\
\hline & GK 1.7 & $66.7 \mathrm{~b}$ & 8.7 & $0.61 \mathrm{~b}$ & 12.1 \\
\hline & GK 2.6 & $91.0 \mathrm{a}$ & 8.7 & $0.83 \mathrm{a}$ & 9.77 \\
\hline & Mean & 39.2 & 6.3 & 0.82 & 13.6 \\
\hline & Significance & $* *$ & n.s. & $* * *$ & n.s. \\
\hline \multirow{6}{*}{147 DAT } & Control & $37.6 \mathrm{c}$ & 7.6 & 0.85 & 8.21 \\
\hline & GK 1.2 & $68.3 \mathrm{~b}$ & 7.0 & 0.88 & 4.05 \\
\hline & GK 1.7 & $87.3 \mathrm{ab}$ & 8.7 & 0.82 & 11.4 \\
\hline & GK 2.6 & $95.0 \mathrm{a}$ & 7.3 & 0.83 & 5.14 \\
\hline & Mean & 60.6 & 7.6 & 0.85 & 7.54 \\
\hline & Significance & $* *$ & n.s. & n.s. & n.s. \\
\hline
\end{tabular}

GK-1.2, GK-1.7 and GK-2.6 indicate the Grass Killer treatments at 1.2, 1.7 and $2.6 \mathrm{~km}$ per hour working speeds, respectively. Control $=$ hoeing machine. The mean values in each column followed by different Roman letters are significantly different according to ${ }^{*} p \leq 0.05 ;{ }^{* *} p \leq 0.01 ;{ }^{* *} p \leq 0.001 . \mathrm{R}=$ richness and $\mathrm{E}=$ evenness.

The Control (hoeing machine) showed a significantly lower percentage of weed soil coverage compared to the Grass Killer treatments also at 35, 69 and 147 days after weed control treatments, followed by the GK 1.2, whereas the GK 2.6 showed the highest value at all the stages (Table 3). Community structural parameters highlighted small significant differences among treatments, with GK 1.7 characterized by a lower homogeneity of the community at 35 and 69 days after treatment (e values of 0.56 and 0.61 vs. mean values of 0.83 and 0.86 at 35 and 69 DAT, respectively) and a lower incidence of perennials at 35 DAT.

\subsection{Olive Tree Growth, Physiological Parameters and Root Development}

The trunk cross sectional area (TCSA) of the young olive trees registered at the end of the growing season 2020 was similar between the studied weed control treatments. TCSA increased $0.55 \mathrm{~cm}^{2}$ for the Control and $0.65,0.79$ and $0.83 \mathrm{~cm}^{2}$ for $1.2,1.7$ and $2.6 \mathrm{~km} \mathrm{~h}^{-1}$ forward speeds of the Grass Killer, respectively (Figure 5). Despite the slightly higher TCSA increase registered of the GK treatment compared to the hoeing machine, no significant differences were found. The same results were shown for the total tree height (Figure 6) and the amount of pruning material removed in the first $0.6 \mathrm{~m}$ of trunk above the soil at the end of the growing season 2020 (Figure 7).

The relative water content (RWC) of the leaves of the young olive trees was $46.7 \%$ as an average value for the GK treatments and $60.3 \%$ for the Control (Table 4). Despite the lower value registered for GK, which could be due to a dehydration effect (drought stress) on the trees, the reduced number of replicates did not allow a statistical analysis. No significant differences were found between the tested treatments regarding the net photosynthetic rate, the stomatal conductance, the $\mathrm{CO}_{2}$ intercellular concentration and the transpiration rate measured on fully expanded leaves (Table 4). 


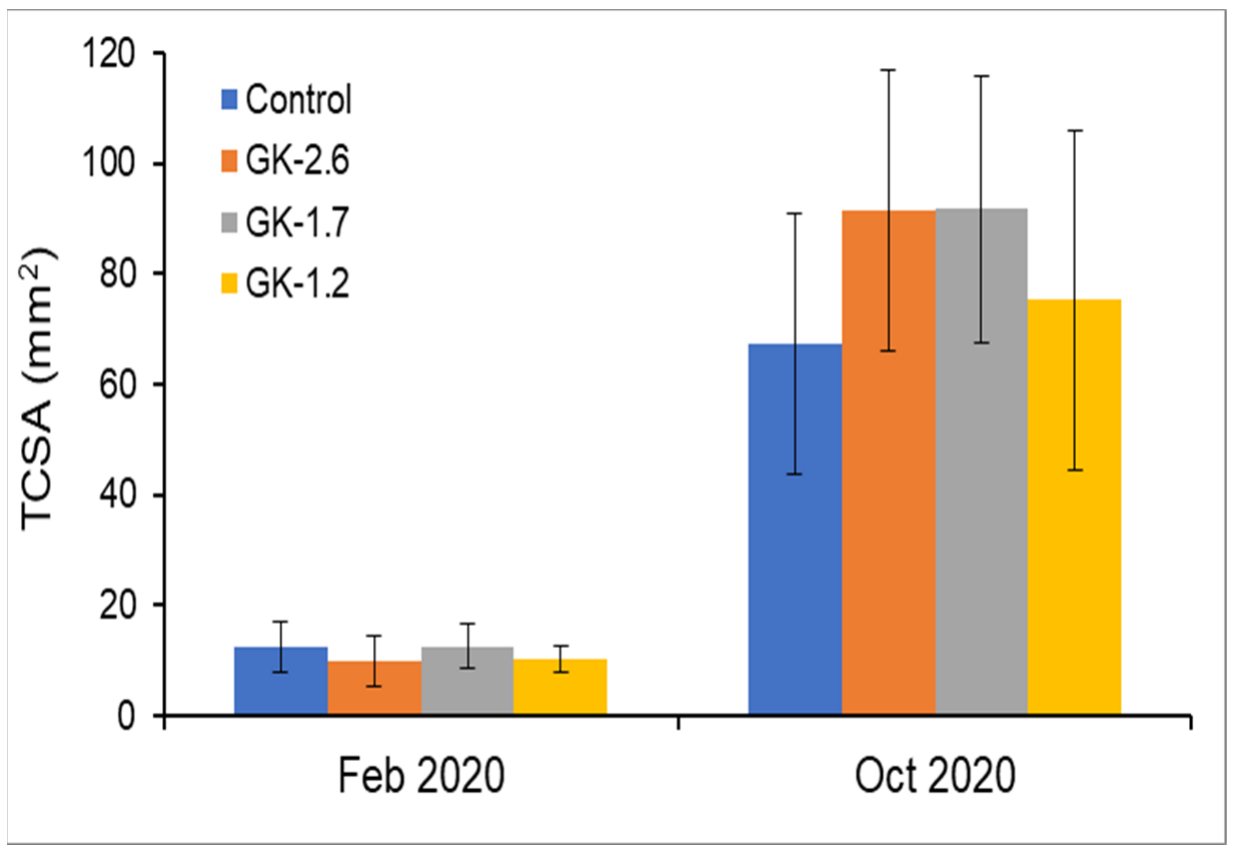

Figure 5. Trunk cross sectional area (TCSA) at the beginning and at the end of growing season in 2020. GK-1.2, GK-1.7 and GK-2.6 indicate the Grass Killer treatments at 1.2, 1.7 and $2.6 \mathrm{~km}$ per hour working speeds, respectively. Control = hoeing machine. No significant differences were recorded between treatments according to Tukey-Kramer HSD test $(p<0.05)$. Data are means \pm standard deviation of 30 replicates for Control and 10 for each forward speed of Grass Killer (GK) treatment.

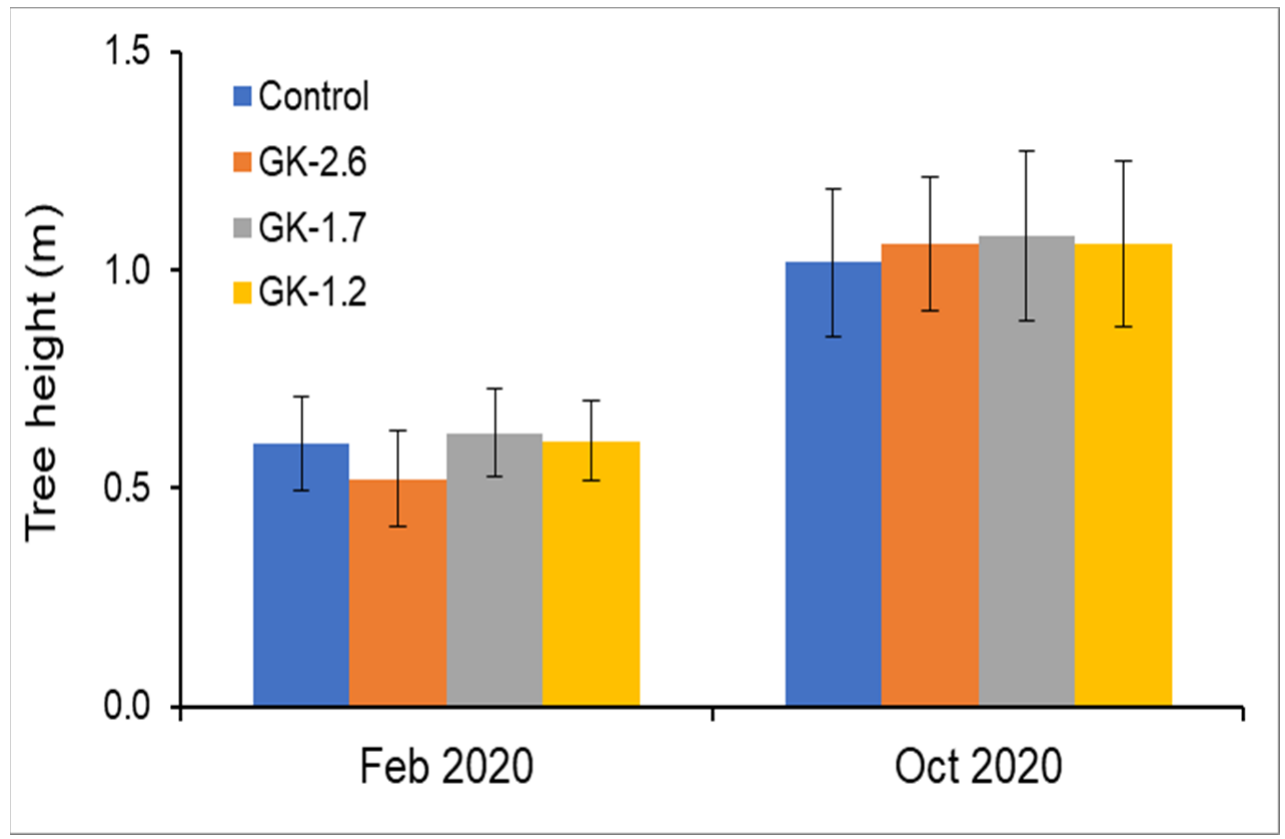

Figure 6. Total tree height at the beginning and at the end of the growing season in 2020. GK-1.2, GK-1.7 and GK-2.6 indicate the Grass Killer treatments at 1.2, 1.7 and $2.6 \mathrm{~km}$ per hour working speeds, respectively. Control = hoeing machine. No significant differences were recorded between treatments according to Tukey-Kramer HSD test $(p<0.05)$. Data are means \pm standard deviation of 30 replicates for Control and 10 for each forward speed of Grass Killer (GK) treatment. 


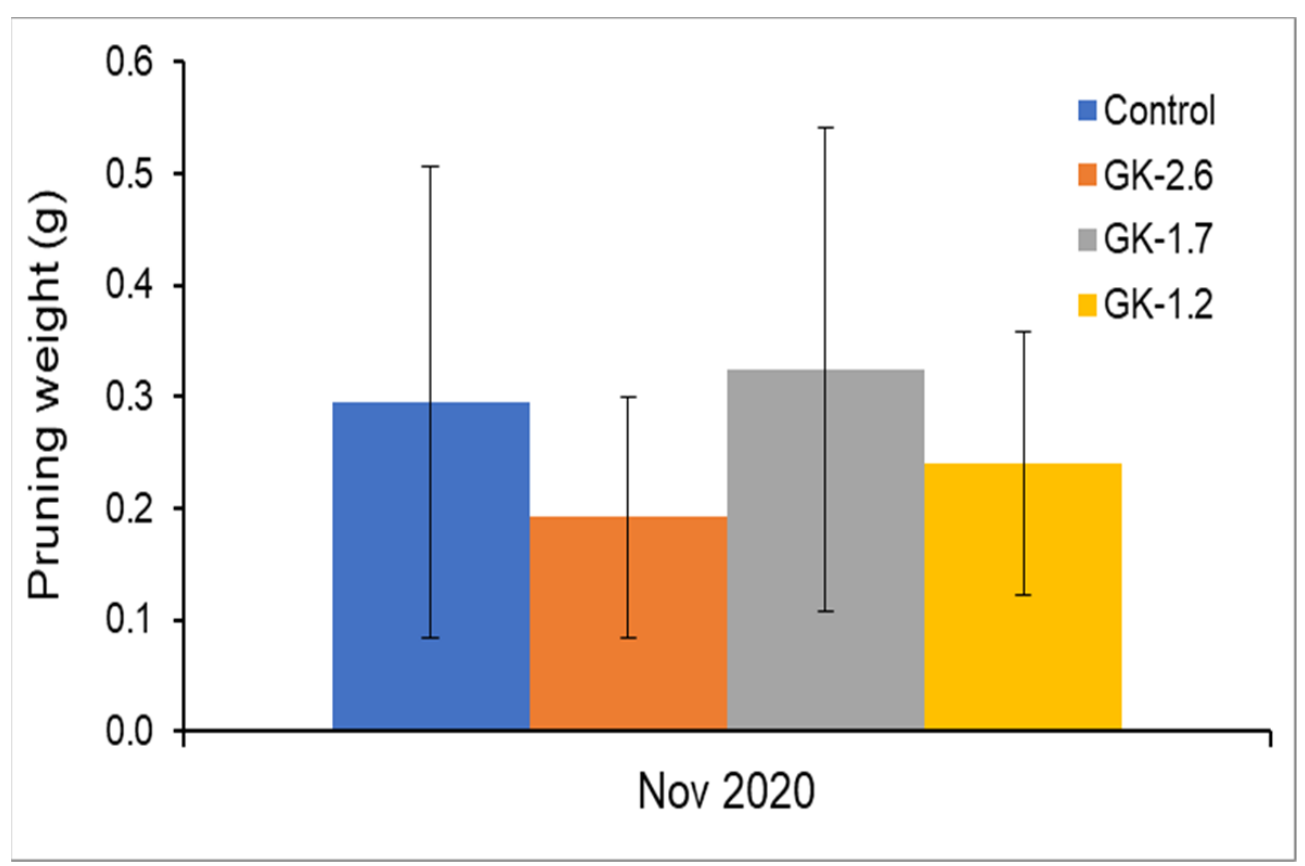

Figure 7. Pruning weight measured at the end of the growing season 2020. GK-1.2, GK-1.7 and GK-2.6 indicate the Grass Killer treatments at 1.2, 1.7 and $2.6 \mathrm{~km}$ per hour working speeds, respectively. Control = hoeing machine. No significant differences were recorded between treatments according to Tukey-Kramer HSD test $(p<0.05)$. Data are means \pm standard deviation of 30 replicates for Control and 10 for each forward speed of Grass Killer (GK) treatment.

Table 4. Plant water status and diurnal leaf gas exchange registered at the beginning of August 2020 (48 days after the weed control treatment in the June test).

\begin{tabular}{|c|c|c|c|c|c|}
\hline & $\begin{array}{c}\text { RWC } \\
(\%)\end{array}$ & $\begin{array}{c}\text { Net Photosynthetic } \\
\text { Rate } \\
\left(\mu \mathrm{mol} \mathrm{CO} \mathrm{m}^{-2} \mathrm{~s}^{-1}\right)\end{array}$ & $\begin{array}{c}\text { Stomatal } \\
\text { Conductance } \\
\left(\mathrm{mmol} \mathrm{H}_{2} \mathrm{O} \mathrm{m}^{-2} \mathrm{~s}^{-1}\right)\end{array}$ & $\begin{array}{c}\mathrm{CO}_{2} \text { Intercellular } \\
\text { Concentration } \\
\left(\mu \mathrm{mol} \mathrm{CO} \mathrm{mol}^{-1}\right)\end{array}$ & $\begin{array}{c}\text { Transpiration Rate } \\
\left(\mathrm{mmol} \mathrm{H}_{2} \mathrm{O} \mathrm{m}^{-2} \mathrm{~s}^{-1}\right)\end{array}$ \\
\hline Control & 60.27 & $23.5 \pm 6.92$ & $0.36 \pm 0.196$ & $244 \pm 40.6$ & $6.18 \pm 2.582$ \\
\hline Grass Killer & 46.69 & $22.5 \pm 0.98$ & $0.33 \pm 0.058$ & $253 \pm 12.1$ & $5.94 \pm 0.198$ \\
\hline
\end{tabular}

Since no significant differences were found between the Grass Killer 1.2, 1.7 and 2.6 km per hour working speed treatments, data were analysed together. No significant differences were recorded between Grass Killer and the Control (hoeing machine) according to Tukey-Kramer HSD test $(p<0.05)$.

Root trait measurements are shown as root length density (RLD) and average root diameter. As shown in Figures 8 and 9, comparing the Control with the average of all the GK treatments, significant differences of RLD were found in the last sampling date (April 2021), no differences were recorded in the other dates, whilst a lower RLD was evident in the November sampling date for all treatments compared with the other dates.

The different forward speeds of the GK machine shows different root development (Figure 9). In July 2020, RLD was lower for the $1.2 \mathrm{~km} \mathrm{~h}^{-1}$ than the other two forward speeds. In November 2020, $1.7 \mathrm{~km} \mathrm{~h}^{-1}$ showed a lower RDL, while in the last sampling date (April 2021), no differences between GK forward speeds were found but all the GK showed a lower RLD than the Control.

Concerning the average root diameter, no differences were found between GK treatments and the Control (Figure 10) and between the different GK forward speeds within each sampling date (Figure 11), but lower values were measured in the last sampling date (April 2021). 


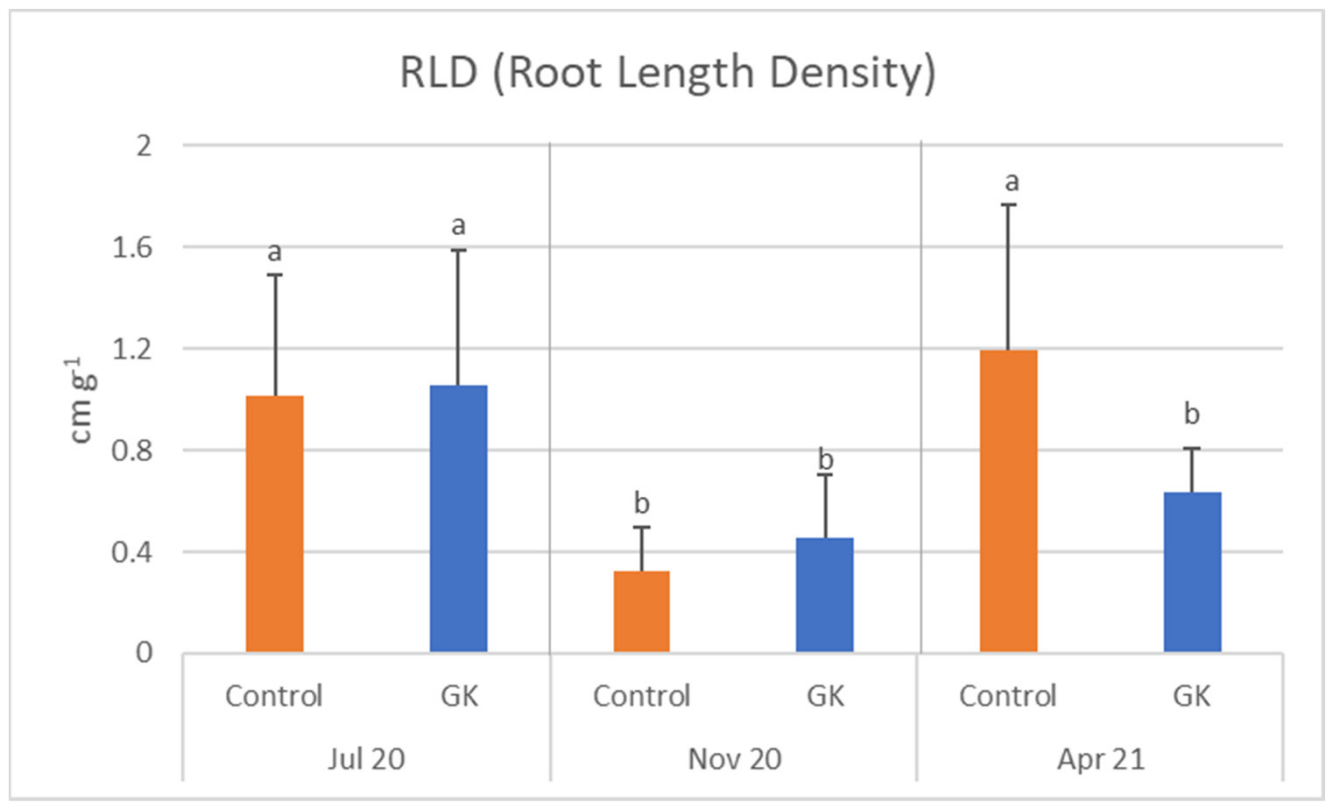

Figure 8. Root length density (RLD, measured as total root length soil weight ${ }^{-1}$ ) in the three sampling dates. Since no significant differences were found between the Grass Killer (GK) 1.2, 1.7 and $2.6 \mathrm{~km}$ per hour working speed treatments, data were analysed together. Control = hoeing machine. Data are means \pm standard deviation, different letters indicate significative differences between treatments and sampling dates for HSD Tukey-Kramer HSD test $(p<0.05)$.

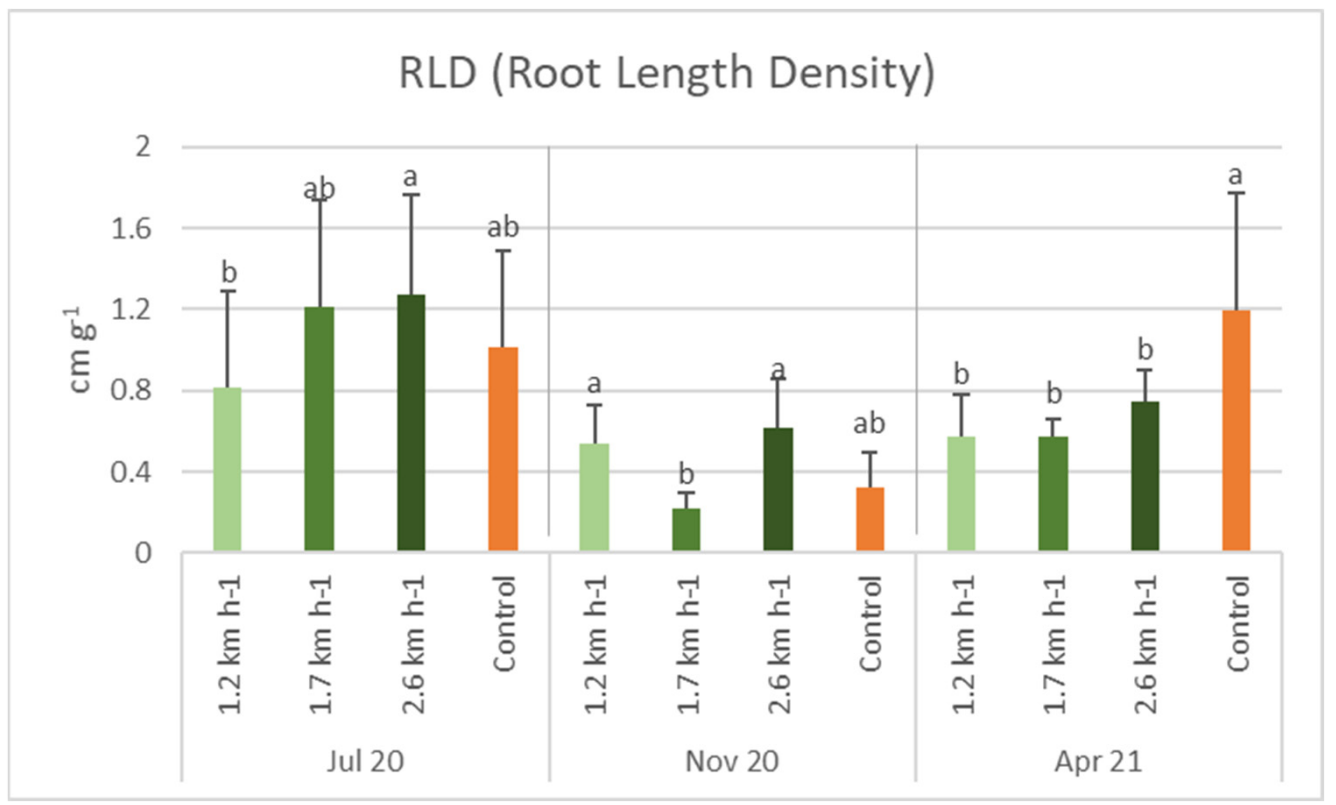

Figure 9. Root length density (RLD, measured as total root length soil weight ${ }^{-1}$ ) in the three sampling dates. $1.2 \mathrm{~km} \mathrm{~h}^{-1}, 1.7 \mathrm{~km} \mathrm{~h}^{-1}$ and $2.6 \mathrm{~km} \mathrm{~h}^{-1}$ indicate the Grass Killer treatments at 1.2, 1.7 and $2.6 \mathrm{~km}$ per hour working speeds, respectively. Control = hoeing machine. Data are means \pm standard deviation, different letters indicate significant differences within each sampling date according to Tukey-Kramer HSD test $(p<0.05)$. 


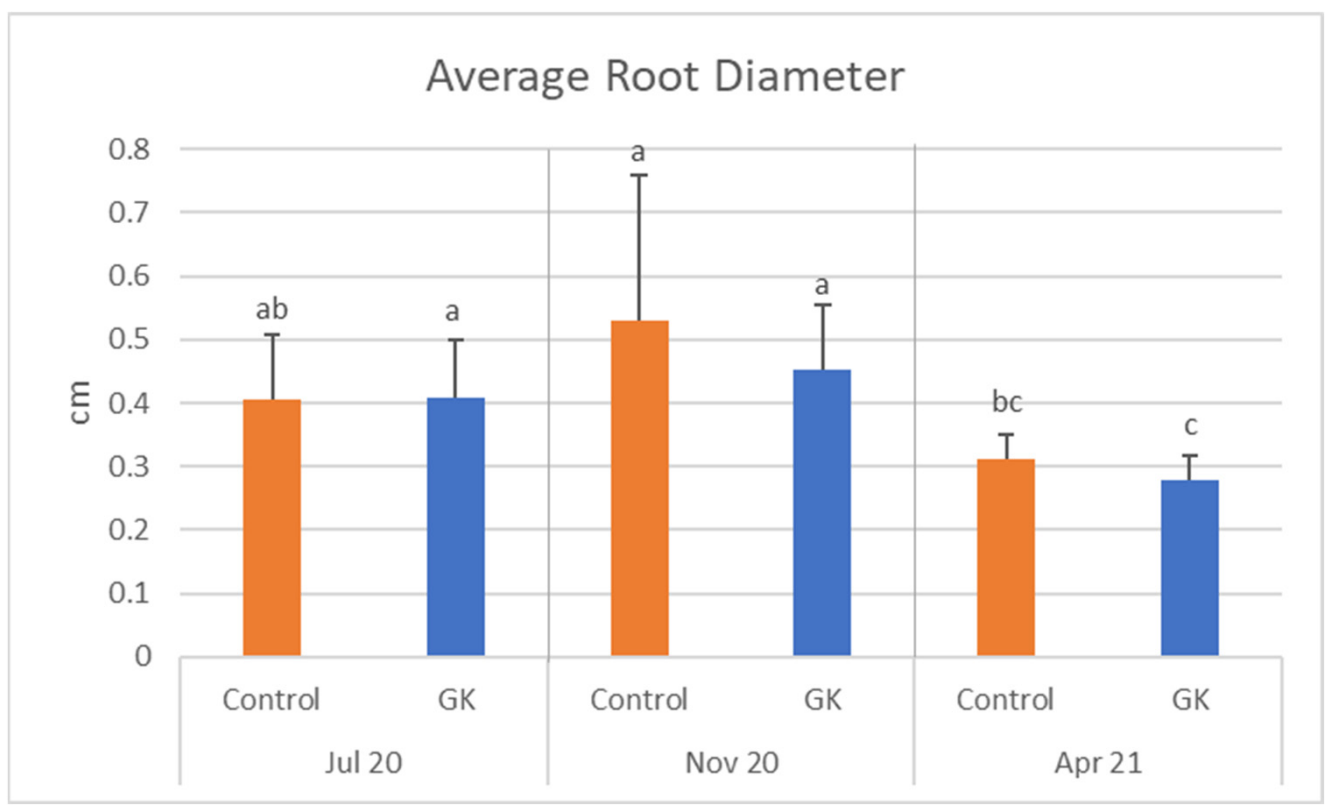

Figure 10. Average root diameter in the three sampling dates. Since no significant differences were found between the Grass Killer (GK) 1.2, 1.7 and 2.6 km per hour working speed treatments, data were analysed together. Control = hoeing machine. Data are means \pm standard deviation, different letters indicate significative differences between treatments and sampling dates according to Tukey-Kramer HSD test $(p<0.05)$.

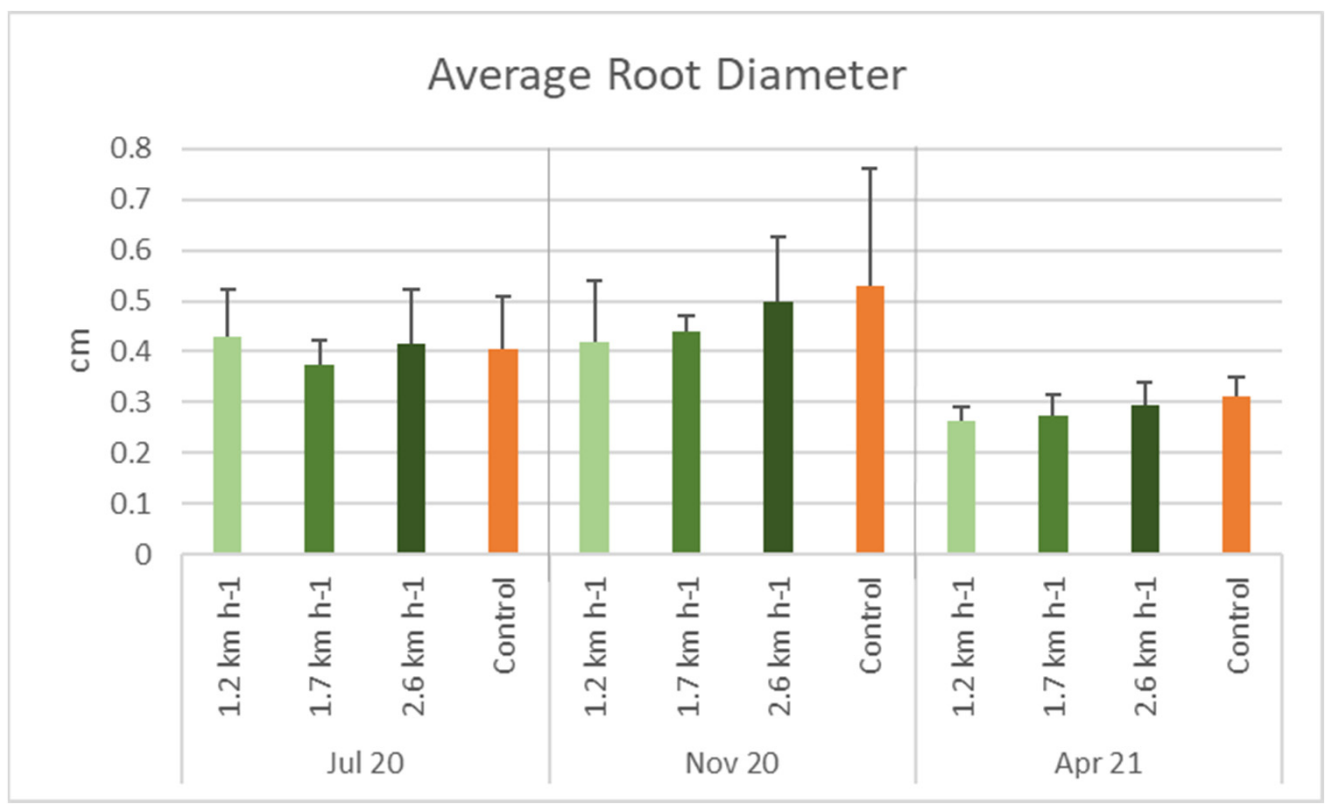

Figure 11. Average root diameter in the three sampling dates and according to the different applied GK treatments. $1.2 \mathrm{~km} \mathrm{~h}^{-1}, 1.7 \mathrm{~km} \mathrm{~h}^{-1}$ and $2.6 \mathrm{~km} \mathrm{~h}^{-1}$ indicate the Grass Killer treatments at 1.2, 1.7 and $2.6 \mathrm{~km}$ per hour working speeds, respectively. Control = hoeing machine. Data are means \pm standard deviation. No significant differences were recorded between GK treatments within each sampling date according to Tukey-Kramer HSD test $(p<0.05)$.

\subsection{Soil Characteristics}

The soil temperature and moisture at $10 \mathrm{~cm}$ depth recorded on 20 July 2020 did not show significant differences between applied weed control treatments, whereas a significant difference was registered for the soil moisture on 19 January 2021 (Table 5). 
Table 5. The soil temperature and moisture at $10 \mathrm{~cm}$ depth were recorded on 20 July 2020 after the June test and on 19 January 2021, for the June and November test.

\begin{tabular}{ccccc}
\hline & \multicolumn{2}{c}{ 20 July 2020 } & \multicolumn{2}{c}{ 19 January 2021 } \\
\hline & $\begin{array}{c}\text { Soil Temperature } \\
\left({ }^{\circ} \mathbf{C}\right)\end{array}$ & $\begin{array}{c}\text { Soil Moisture } \\
(\mathbf{\%})\end{array}$ & $\begin{array}{c}\text { Soil Temperature } \\
\left({ }^{\circ} \mathbf{C}\right)\end{array}$ & $\begin{array}{c}\text { Soil Moisture } \\
\mathbf{( \% )}\end{array}$ \\
\hline Control & $27.4 \pm 0.33 \mathrm{a}$ & $11.7 \pm 1.72 \mathrm{a}$ & $5.13 \pm 0.67 \mathrm{a}$ & $22.4 \pm 4.72 \mathrm{a}$ \\
Grass Killer & $27.3 \pm 0.19 \mathrm{a}$ & $10.5 \pm 0.43 \mathrm{a}$ & $5.54 \pm 0.27 \mathrm{a}$ & $13.2 \pm 6.72 \mathrm{~b}$ \\
\hline
\end{tabular}

Since no significant differences were found between the Grass Killer 1.2, 1.7 and $2.6 \mathrm{~km}$ per hour working speed treatments, data were analysed together. Data are means \pm standard deviation, different letters indicate significant differences within each sampling date according to Tukey-Kramer HSD test $(p<0.05)$.

On the basis of the simplified cost-benefit estimated for this study (Table 6), the intermediate speed adopted (i.e., $1.7 \mathrm{~km} \mathrm{~h}^{-1}$ ) showed a performance comparable with the hoeing. This result might be verified in the most frequent operating contexts where also chemical weeding is an option; however, towards the complete eradication of synthetic herbicides use, the environmental benefits of the Grass Killer should be considered besides the economic assessment (e.g., the organic matter preservation and maintenance of a structure more favourable to gas exchanges and root development.

Table 6. Cost-benefit analysis of the two tested weed control practices. GK-1.2, GK-1.7 and GK-2.6 indicate the Grass Killer treatments at 1.2, 1.7 and $2.6 \mathrm{~km}$ per hour working speeds, respectively. Control = hoeing machine.

\begin{tabular}{|c|c|c|c|c|}
\hline & $\begin{array}{l}\text { Working Speed } \\
\quad\left(\mathrm{km} \mathrm{h}^{-1}\right)\end{array}$ & $\begin{array}{l}\text { Productivity } \\
\quad\left(\mathrm{ha} \mathrm{h}^{-1}\right)\end{array}$ & $\begin{array}{l}\text { Water Consumption } \\
\left(\mathrm{L} \mathrm{ha}^{-1}\right)\end{array}$ & $\begin{array}{c}\text { Cost } \\
\left(\text { Euros ha }^{-1}\right)\end{array}$ \\
\hline Control & 3.0 & 0.50 & 0.00 & 169.00 \\
\hline GK-1.2 & 1.2 & 0.21 & 1345 & 261.90 \\
\hline GK-1.7 & 1.7 & 0.30 & 950 & 183.33 \\
\hline GK-2.6 & 2.6 & 0.46 & 621 & 119.57 \\
\hline
\end{tabular}

\section{Discussion}

Results obtained from our study highlighted that the Grass Killer machine has, in terms of weed control, an effect comparable to the Control and showed the potential role of the high-pressure water weeder to represent a valuable alternative to the common hoeing practices. The Grass Killer showed, indeed, a strong reduction of weed presence, with the highest effect on the space close to the olive trees (i.e., the row space) with only one treatment, confirming previous recent results [41]. This effectiveness appeared strictly related to the operative speed of the machine, with the best performances with the lowest one (Tables 2 and 3). Moreover, the lower forward speeds (1.2 and 1.7) showed a significant reduction of perennial species, commonly representing among the most competitive and difficult in removal ones in orchards and usually selected by mowing [13,20]. As previously reported by Mia et al. [27], this result may be due to the ability of the water jet to destroy the root system in addition to breaking down the weed foliage.

On the other hand, the high-pressure water blasting system did not show an efficient capacity to maintain the parallelism of the operating head to the soil surface in both tests, thus directly influencing the weeding ability. This was confirmed by the lack of sufficient homogeneity of depth, an aspect currently studied and implemented with the manufacturer. The weeding effect is also directly related to the distance from the nozzle to the weed; a greatest effect could be achieved by reducing the distance from consecutive nozzle passages by 4 to $2 \mathrm{~cm}$. This implementation can be obtained at the same working speed by increasing the nozzle plate speed or the number of nozzles in the plate.

Since the Grass Killer was effective in reducing weed cover without totally eradicating it, as it happens in the Control with hoeing (Table 2), GK may play a role in preserving weed community diversity, avoiding the selection of new flora after the treatment. At the same time, individuals surviving after GK treatment continue to cover the soil without competing 
directly for resources with crops and can complete their life cycle. This result indicates the Grass Killer management might be a good strategy to reduce the effect of weed control in impoverishing the seed bank of olive orchards when compared with other perennial crops $[20,42]$ and, at the same time, to magnify the role of ecosystem service provision by weeds $[43,44]$. Moreover, maintaining the soil coverage along the row preserves organic matter content and soil moisture, without affecting the temperature in the first soil layers and preventing erosion and run-off. All these parameters result very important for the appropriate root development and canopy growth of the young olive trees.

As far as the effect on the soil is concerned, in the tests that were performed, it was limited to the first few centimetres of soil, and this aspect, compared to the Control, clearly showed the advantage of the high-pressure water blasting system in limiting the evaporation of water and the oxidation of the organic matter of the soil by maintaining a living mulching of the natural weeds, even along the row [8]. This represents a critical aspect in all machines operating from $10 \mathrm{~cm}$ working depths and more so that the $2 \mathrm{~cm}$ depth of the high-pressure water weeder is an aspect of considerable interest.

The GK did not affect the physiological behaviour or the root development of the trees in comparison to the Control, even if some differences were recorded depending on the forward speed. This is in line with the reduced impact of GK on the soil, potentially positively contributing to preserve biological soil fertility in high-density olive orchards [17,18]. According to our study the high-pressure water blast machine applied along the row did not affect the growth of the irrigated young olive trees in terms of trunk cross sectional area (TCSA), plant height and the removed pruning material compared to the hoeing machine (Figures 5-7). Such results confirm that, as seen for the whole orchard soil floor management in a high-density planting system [6], the maintenance of a week soil cover along the row (instead of completely removing it by tillage) does not compromise the vegetative growth of the olive trees during the first years after planting. Moreover, the presence of a living mulch below the olive trees can ensure an increased biological diversity and may imply a higher resilience of the whole agro-ecosystem with positive effects on fruit yield and quality, as reported in recent studies about organic management of young vineyards [45], apple [46] or olive [47] orchards.

Last but not least, the high-pressure water blast machine does not come into direct contact with the olive trees compared to the traditional inter-row hoeing machine, thus significantly limiting the potential damages that can affect the delicate trunk of the young olive trees during the first years after planting.

According to the current perspective of reducing the application of chemicals for the weed control and a sustainable management of the biodiversity of the spontaneous flora of the soil floor, even in a high-density olive orchard, the proposed solution is of considerable interest in a localized intra-row application, representing a viable solution for both weed competitive effect reduction and spontaneous flora diversity preserving in intensive system such as super-high-density olive orchards. This technology, which still requires some implementation, has some critical issues related to the distribution method, speed and working depth and width along the row. The positive effect in terms of evapotranspiration reduction and oxygenation of the soil organic matter is not irrelevant and will require in-depth studies. The quantitative content of water used (about $10001 \mathrm{ha}^{-1}$ ) can allow to modify the efficiency of the intervention according to specific needs, even doubling it in specific points where necessary in a perspective of precision agriculture.

The field test confirmed that high-pressure water blast systems represent a sustainable weeding management alternative to the intra-row hoeing machine. The treatment with high-pressure water was comparable to that with the effectiveness of the intra-row hoeing machine in terms of weed reduction, effect on specific weed groups (annual and perennial) preserving weed diversity, soil characteristics (temperature and moisture) and in terms of the effect on tree growth depending on the adopted solution. Nevertheless, further research is needed to optimize the working parameters in synergy with the manufacturer. 


\begin{abstract}
Author Contributions: Conceptualization, A.A. and E.M.L.; methodology, E.M.L., A.A., V.G., M.Z. and D.N.; validation, A.A. and E.M.L.; formal analysis, A.A., V.G., C.C. and E.M.L.; investigation, E.M.L.; data curation, V.G., M.Z., C.C. and E.M.L.; writing-original draft preparation, A.A., C.C. and E.M.L.; writing-reviewing and editing, A.A., V.G., M.Z., C.C., D.N. and E.M.L.; supervision, A.A. and E.M.L.; project administration, E.M.L.; funding acquisition, A.A. and E.M.L. All authors have read and agreed to the published version of the manuscript.
\end{abstract}

Funding: This study was carried out in the frame of the MOLTI project (Decree n. 13938/7110/2018) funded by the Italian Ministry of Agriculture (MiPAAF).

Acknowledgments: Authors are grateful to Caffini Spa for machine and support availability.

Conflicts of Interest: The authors declare no conflict of interest.

\title{
References
}

1. Tous, J.; Romero, A.; Plana, J.; Baiges, F. Planting density trial with “Arbequina” olive cultivar in Catalonia (Spain). Acta Hortic. 1999, 474, 177-179. [CrossRef]

2. Connor, D.J.; Gómez-del-Campo, M.; Rousseaux, M.C.; Searles, P.S. Structure, management and productivity of hedgerow olive orchards: A review. Sci. Hortic. 2014, 169, 71-93. [CrossRef]

3. Rosati, A.; Paoletti, A.; Caporali, S.; Perri, E. The role of tree architecture in super high density olive orchards. Sci. Hortic. 2013, 161, 24-29. [CrossRef]

4. Rosati, A.; Paoletti, A.; Al Hariri, R.; Morelli, A.; Famiani, F. Partitioning of dry matter into fruit explains cultivar differences in vigor in young olive (Olea europaea L.) trees. HortScience 2018, 53, 491-495. [CrossRef]

5. Rosati, A.; Paoletti, A.; Al Hariri, R.; Famiani, F. Fruit production and branching density affect shoot and whole-tree wood to leaf biomass ratio in olive. Tree Physiol. 2018, 38, 1278-1285. [CrossRef]

6. Assirelli, A.; Romano, E.; Bisaglia, C.; Lodolini, E.M.; Neri, D.; Brambilla, M. Canopy Index Evaluation for Precision Management in an Intensive Olive Orchard. Sustainability 2021, 13, 8266. [CrossRef]

7. Assirelli, A.; Liberati, P. Simulation modelling of mechanical systems for intra-row weeding in a precision farming approach. Span. J. Agric. Res. 2022, 20, e0201. [CrossRef]

8. Gucci, R.; Caruso, G.; Bertolla, C.; Urbani, S.; Taticchi, A.; Esposto, S.; Servili, M.; Sifola, M.I.; Pellegrini, S.; Pagliai, M.; et al. Changes of soil properties and tree performace induced by soil management in a high-density olive orchard. Eur. J. Agron. 2012, 41, 18-27. [CrossRef]

9. Atkinson, D. The distribution and effectiveness of the roots of tree crops. Hortic. Rev. 1980, 2, 424-490.

10. Tworkoski, T.J.; Glenn, D.M. Yield, shoot and root growth, and physiological responses of mature peach trees to grass competition. HortScience 2001, 36, 1214-1218. [CrossRef]

11. Moriana, A.; Fereres, E. Plant indicators for scheduling irrigation of young olive trees. Irrig. Sci. 2002, $21,83-90$.

12. Metzidakis, I.; Martinez-Vilela, A.; Castro Nieto, G.; Basso, B. Intensive olive orchards on sloping land: Good water and pest management are essential. J. Environ. Manag. 2008, 89, 120-128. [CrossRef]

13. Hammermeister, A.M. Organic weed management in perennial fruits. Sci. Hortic. 2016, 208, 28-42. [CrossRef]

14. Loddo, D.; Allegri, A.; Bartolini, D.; Sattin, M. Gestione delle infestanti nei fruttiferi: Vite, olivo e altre colture arboree. In Infestanti Emergenti e Riduzione di Disponibilità di Erbicidi, Proceedings of the 21st S.I.R.F.I. Conference, Bari, Italy, 16 ottobre 2018; Vidotto, F., de Paolo, F., Ferrero, A., Eds.; SIRFI: Bari, Italy, 2018; pp. 163-174.

15. Fracchiolla, M.; Caramia, D.; Lasorella, C.; Montemurro, P. Ground cover management strategies in an Apulian oil-producing olive grove: Agronomic and ecological assessment proposals. Adv. Hortic. Sci. 2013, 27, 44-54.

16. Toscano, P.; Iannotta, N.; Scalercio, S. Botanical and agricultural aspects: Agronomic techniques and orchard management. In Agricultural and Food Biotechnology of Olea Europaea and Stone Fruits; Muzzalupo, I., Micali, S., Eds.; Bentham Science Publishers: Sharjah, United Arab Emirates, 2015; pp. 2-74; ISBN 978-1-68108-002-4.

17. Turrini, A.; Caruso, G.; Avio, L.; Gennai, C.; Palla, M.; Agnolucci, M.; Tomei, P.E.; Giovannetti, M.; Gucci, R. Protective green cover enhances soil respiration and native mycorrhizal potential compared with soil tillage in a high-density olive orchard in a long-term study. Appl. Soil Ecol. 2017, 116, 70-78. [CrossRef]

18. Vignozzi, N.; Agnelli, A.E.; Brandi, G.; Gagnarli, E.; Goggioli, D.; Lagomarsino, A.; Pellegrini, S.; Simoncini, S.; Simoni, S.; Valboa, G.; et al. Soil ecosystem functions in a high-density olive orchard managed by different soil conservation practices. Appl. Soil Ecol. 2019, 134, 64-76. [CrossRef]

19. Scarfone, A.; Picchio, R.; Del Giudice, A.; Latterini, F.; Mattei, P.; Santangelo, E.; Assirelli, A. Semi-automatic guidance vs. Manual guidance in agriculture: A comparison of work performance in wheat sowing. Electronics 2021, 10, 825. [CrossRef]

20. Carpio, A.J.; Lora, Á.; Martín-Consuegra, E.; Sánchez-Cuesta, R.; Tortosa, F.S.; Castro, J. The influence of the soil management systems on aboveground and seed bank weed communities in olive orchards. Weed Biol. Manag. 2020, 20, 12-23. [CrossRef]

21. Del Giudice, A.; Assirelli, A.; Gallucci, F.; Bellacima, R.; Pari, L.; Santangelo, E. Production of energy feedstock from the riparian vegetation of Arundo donax (L.): Suitability of the chopping systems. Ecol. Eng. 2017, 102, 459-467. [CrossRef] 
22. Assirelli, A.; Liberati, P.; Santangelo, E.; Del Giudice, A.; Civitarese, V.; Pari, L. Evaluation of sensors for poplar cutting detection to be used in intra-row weed control machine. Comput. Electron. Agric. 2015, 115, 161-170. [CrossRef]

23. Camposeo, S.; Vivaldi, G.A. Short-term effects of de-oiled olive pomace mulching application on a young super high-density olive orchard. Sci. Hortic. 2011, 129, 613-621. [CrossRef]

24. Russo, G.; Vivaldi, G.A.; de Gennaro, B.; Camposeo, S. Environmental sustainability of different soil management techniques in a high-density olive orchard. J. Clean. Prod. 2015, 107, 498-508. [CrossRef]

25. Assirelli, A.; Santangelo, E.; Spinelli, R.; Acampora, A.; Croce, S.; Civitarese, V.; Pari, L. Mechanization of rhizome extraction in giant reed (Arundo donax L.) nurseries. Appl. Eng. Agric. 2013, 29, 489-494. [CrossRef]

26. Calderón, M.J.; de Luna, E.; Gómez, J.A.; Hermosín, M.C. Herbicide monitoring in soil, runoff waters and sediments in an olive orchard. Sci. Total Environ. 2016, 569, 416-422. [CrossRef]

27. Mia, M.J.; Massetani, F.; Murri, G.; Facchi, J.; Monaci, E.; Amadio, L.; Neri, D. Integrated weed management in high density fruit orchards. Agronomy 2020, 10, 1492. [CrossRef]

28. Sánchez-Moreno, S.; Castro, J.; Alonso-Prados, E.; Alonso-Prados, J.L.; García-Baudín, J.M.; Talavera, M.; Durán-Zuazo, V.H. Tillage and herbicide decrease soil biodiversity in olive orchards. Agron. Sustain. Dev. 2015, 35, 691-700. [CrossRef]

29. Mia, M.J.; Massetani, F.; Murri, G.; Neri, D. Sustainable alternatives to chemicals for weed control in the orchard-A Review Hortic. Sci. 2020, 47, 1-12. [CrossRef]

30. Turner, R.J.; Davies, G.; Moore, H.; Grundy, A.C.; Mead, A. Organic weed management: A review of the current UK farmer perspective. Crop Prot. 2007, 26, 377-382. [CrossRef]

31. Bokszczanin, K.Ł.; Wrona, D.; Przybyłko, S. Influence of an alternative soil management system to herbicide use on tree vigor yield, and quality of apple fruit. Agronomy 2021, 11, 58. [CrossRef]

32. Leblanc, M.; Cloutier, D. La haute technologie au service de la lutte aux mauvaises herbes dans un context d'agriculture biologique. Phytoprotection 2006, 87, 77-81. [CrossRef]

33. Assirelli, A.; Caracciolo, G.; Cacchi, M.; Sirri, S.; Pallottino, F.; Costa, C. Evaluation of the Detachment Force Needed for the Thinning of Green Peach Fruits. Sustainability 2018, 10, 2291. [CrossRef]

34. Ishida, Y.; Okamoto, T.; Imou, K.; Kaizu, Y. A study on physical weeding using a water jet. J. Jpn. Soc. Agric. Mach. 2005, 67, 93-99.

35. Folgelberg, F. Research on Pest Control and Pesticide Reduction in Sweden, Denmark and the Netherlands, Ongoing Work and New Ideas for the Future; Report; Department of Agricultural Engineering, Swedish University of Agricultural Sciences: Alnarp, Sweden, 2001; p. 31.

36. Fogelberg, F.; Blom, A. Water-jet cutting for weed control. In Proceedings of the 5th EWRS Workshop on Physical Weed Control, Pisa, Italy, 11-13 March 2002; European Weed Research Society: Belgrade, Serbia, 2002; p. 237.

37. Fogelberg, F. Water-jet cutting of potato tops-Some experiences from Sweden 2003. In Proceedings of the 6th European Weed Research Society Workshop on Physical and Cultural Weed Control, Lillehammer, Norway, 8-10 March 2004; Cloutier, D.C., Ascard, J., Eds.; pp. 127-141.

38. APIMAI, Associazione Provinciale Imprese di Meccanizzazione Agricola. Tariffario 2020 per la Provincia di Ancona. 2020. Available online: https:/ / www.apima.ancona.it/wpcontent/uploads/2020/06/tariffario_2020.pdf (accessed on 6 February 2022).

39. Directive 2009/128/EC of the European Parliament and of the Council. Available online: https:/ / eur-lex.europa.eu/LexUriServ / LexUriServ.do?uri=OJ:L:2009:309:0071:0086:en:PDF (accessed on 6 February 2022).

40. Assirelli, A.; Pignedoli, S. Costo di esercizio delle machine agricole. Cent. Ric. Prod. Anim. 2005, 5, 1-10.

41. Varani, M.; Molari, G.; Mattetti, M.; Ferrari, A. Performance evaluation of a non-chemical weed control machine for vineyards and orchards operating with high pressure cold water. Acta Hortic. 2021, 1311, 533-540. [CrossRef]

42. Bossuyt, B.; Honnay, O. Can the seed bank be used for ecological restoration? An overview of seed bank characteristics in European communities. J. Veg. Sci. 2008, 19, 875-884. [CrossRef]

43. Wood, S.A.; Karp, D.S.; DeClerck, F.; Kremen, C.; Naeem, S.; Palm, C.A. Functional traits in agriculture: Agrobiodiversity and ecosystem services. Trends Ecol. Evol. 2015, 30, 531-539. [CrossRef]

44. Mézière, D.; Petit, S.; Granger, S.; Biju-Duval, L.; Colbach, N. Developing a set of simulation-based indicators to assess harmfulness and contribution to biodiversity of weed communities in cropping systems. Ecol. Indic. 2015, 48, 157-170. [CrossRef]

45. Neri, D.; Polverigiani, S.; Zucchini, M.; Giorgi, V.; Marchionni, F.; Mia, M.J. Strawberry living mulching in an organic vineyard. Agronomy 2021, 11, 1643. [CrossRef] 
46. Mia Md, J.; Furmanczyk, E.M.; Golian, J.; Kwiatkowska, J.; Malusá, E.; Neri, D. Living Mulch with Selected Herbs for Soil Management in Organic Apple Orchards. Horticulturae 2021, 7, 59. [CrossRef]

47. Las Casas, G.; Ciaccia, C.; Iovino, V.; Ferlito, F.; Torrisi, B.; Lodolini, E.M.; Giuffrida, A.; Catania, R.; Nicolosi, E.; Bella, S. Effects of Different Inter-Row Soil Management and Intra-Row Living Mulch on Spontaneous Flora, Beneficial Insects, and Growth of Young Olive Trees in Southern Italy. Plants 2022, 11, 545. [CrossRef] 